\title{
オウトウのアントシアニンおよびルチン含有量と品種間差異
}

\author{
菅原哲也 ${ }^{\S}$, 五十嵐喜治* \\ 山形県工業技術センタ一庄内試験場特産技術部 \\ *山形大学農学部生物資源学科
}

\section{Cultivar Variation and Anthocyanins and Rutin Content in Sweet Cherries (Prunus avium L.)}

\author{
Tetsuya Sugawara ${ }^{\S}$ and Kiharu Igarashi*
}

Yamagata Research Institute of Technology, Shaonai Testing Facility, 25 Sakuragi, Oshikiri-shinden, Mikawa-machi, Yamagata 997-1321

* Faculty of Agriculture, Yamagata University, 1-23 Wakaba-machi, Tsuruoka, Yamagata 997-8555

\begin{abstract}
Major anthocyanins in 13 sweet cherry (Prunus avium L.) cultivars that were grown on a farm of the Yamagata General Agricultural Research Center were identified and quantified to determine the relationship between anthocyanin and flavonoid (rutin) content with identical sugar moiety. The anthocyanins in sweet cherry (Prunus avium L.) cv Benisayaka fruit with deep red skin and flesh were characterized. Anthocyanins were purified from the $5 \%$ acetic acid soluble fraction of fruit purified by Diaion HP-20 and Sephadex LH-20 column chromatography and HPLC, followed by determination of the chemical structure of anthocyanin content by HPLC and ESI-MS spectrometry, and by ${ }^{1} \mathrm{H},{ }^{13} \mathrm{CNMR}$ analysis. Five types of anthocyanins were identified ; cyanidin-3-rutinoside and cyanidin-3-glucoside were the major anthocyanins of the fruit. Peonidin and pelargonidin-3-rutinoside were minor anthocyanins. Cyanidin-3-sophoroside also was present. Concentrations of cyanidin-3-rutinoside in Japanese sweet cherries (7 cultivars) ranged from not detected (n.d.) to $73.8 \mathrm{mg}$ per $100 \mathrm{~g}$ of fresh weight (FW), with the highest content observed in $\mathrm{cv}$ Benisayaka. As the flavonoid of fruit, rutin also was detected in 13 cultivars, with content ranging from 0.7 $-8.7 \mathrm{mg}$ per $100 \mathrm{~g} \mathrm{FW}$ and showed higher correlation $\left(\mathrm{R}^{2}=0.97\right)$ with content of cyanidin-3-rutinoside, a major anthocyanin in sweet-type cherry.

(Received Nov. 9, 2007 ; Accepted Feb. 1, 2008)
\end{abstract}

Keywords : cherry, anthocyanin, rutin, quantification

キーワード : オウトウ, アントシアニン, ルチン, 定量

現在，オウトウの国内収穫量は年間 2 万 800 t（平成 18 年)であり，都道府県別にみた収穫量割合は，山形県が全 国の $72 \%$ を占め, 次いで青森県 (8\%), 山梨県 (6\%)の順 となっている1．オウトウはサクラ属（Prunus L.）のサク ラ亜属 (subgenus Cerasus) 及びウワミズザクラ亜属 (subgenus Padus）に属する果樹類の総称であり, 現在, 野生種 は 20 種程度，主な栽培種は 13 種程度に分類されている. また, この栽培種の中で, 世界中で広く栽培されているの が甘果オウトウ (Prunus avium L.) と酸果オウトウ (Prunus cerasus L.) の 2 種類である ${ }^{2)}$. 特に甘果オウトウは生食用 として重要な位置を占めており, 果実は酸味が少なく甘 味, 果汁に富んでいる. 国内で栽培されるオウトウのほと んどが甘果オウトウであり, 代表的な栽培品種が “佐藤錦”

=997-1321 山形県東田川郡三川町大字押切新田字桜木 25

* =997-8555 山形県鶴岡市若葉町 1-23

$\S$ 連絡先 (Corresponding author), sugawarate@pref.yamagata.jp
である。

山形県農業生産技術試験場では，世界各地の主要なオウ トウが試験的に栽培されており，オウトウの新品種開発， 育種が盛んに行われている. 1991 年には早生の栽培品種で あり, 完熟すると果皮, 果肉にアントシアニン色素を多量 に含有する ‘紅さやか’，および晚生の栽培品種であり，大 玉で肉質の硬い ‘紅秀峰”を新たに品種登録している.

近年, オウトウ果実の生理機能成分として，健康維持や 各種疾病の予防に効果があるとされている，ポリフェノー ル成分が注目されている。しかしながら，欧米等の国外で 栽培されるオウトウについて, アントシアニンやフラボノ イドの健康機能性に関する研究成果が多数報告されている

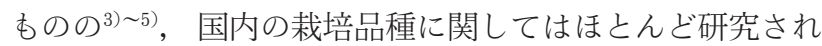
ていない. したがって, 本県で栽培されている, オウトウ 各品種の特徴的なアントシアニンやポリフェノールを明ら かにすることは，オウトウの高付加価值化や健康機能性の 
高い新規なオウトウの育種・開発に大きく寄与するものと 考えられる。

本研究では, “紅さやか’をはじめとして, 国内で栽培さ れている甘果オウトウの主要なアントシアニンを同定・定 量するとともに, その構成・特徵について国外で栽培され るオウトウ各栽培品種との比較を行った. さらにオウトウ に含まれる主要なフラボノイドを同定し, その含有量とアン トシアニン含有量との相関について検討したので報告する.

\section{実 験 方 法}

\section{1. オウトウ果実及び Brix 糖度測定}

分析に用いたオウトウは, 平成 18 年 6 月 26 日に山形県 農業生産技術試験場圃場にて採取した。オウトウの成熟度 は, すべて生食として最適と判断された果実 (適熟果)を 固場内より選抜し, 特に “紅さやか’など, 果皮および果 肉が赤くなる栽培品種については, 赤く完熟した果実を採 取した。国内で栽培される主要な甘果オウトウとして“佐 藤錦’ ‘高砂’ ‘紅さやか’ ‘紅秀峰’ ‘月山錦’ ‘Napoleon’ 'Jabouley'の 7 栽培品種を採取し, さらに国外で栽培され る栽培品種として ‘Conpactlambert’ ‘Greatbigarreau’ 'Van' ‘Redglory' 'Mertonfavrite’ 'Seneca' の 6 品種を 比較のため分析に用いた。採取したオウトウ果実は, Brix 糖度測定後 (手持屈折式糖度計による) , $-55^{\circ} \mathrm{C}$ にて予備 凍結後, $-80^{\circ} \mathrm{C}$ にて保存し, 必要量を解凍し分析に供した.

\section{2. $\mathrm{pH}$, 総ポリフェノール分析}

凍結果実を $2^{\circ} \mathrm{C}$ で半解凍後 (手で押し潰せる硬さ), 種と 軸を取り除き，ホモジナイザー（日本精機 AM-3）にて処 理した (5 分間, 8000 回転). pH の測定は堀場製作所製ガ

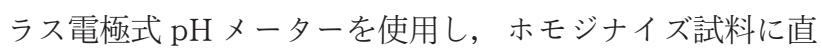

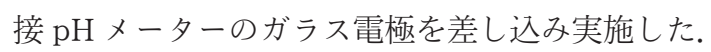

総ポリフェノールの分析は, 凍結果実を $2^{\circ} \mathrm{C} に て$ 半解凍 後, 種と軸を除去し, 重量を正確に秤量した (約 $5 \mathrm{~g}$ ). 直 ちに $80 \%$ エ夕ノール $100 \mathrm{ml}$ を加え, 氷冷しながらホモジ ナイザーにて処理した（5 分間，8000 回転).さらに室温 (約 $20^{\circ} \mathrm{C}$ ) にて 24 時間静置し, ポリフェノール成分の抽出 を行った. 抽出液をろ過 (5A 版) し, ポリフェノール分析 の試料とした。総ポリフェノール含有量はフォーリン・デ ニス法 ${ }^{6}$ により分析した. 定量值は $(+)$ カテキン換算值と して算出した.

\section{HPLC によるアントシアニンの分析}

オウトウ 13 品種の各凍結果実について, 抽出溶媒に $5 \%$ 酢酸 $100 \mathrm{ml}$ を使用し, ポリフェノール抽出と同様の操作 によりアントシアニンの抽出を行った. 抽出液は, 万紙 (5A 版）およびメンブレン $(0.45 \mu \mathrm{m})$ にて順次ろ過し, HPLC 分析の試料とした. HPLC 装置は島津製作所(株) 製 LC-10 A 型を使用した. 分析 HPLC 用のカラムは Mightysil RP18 (4.6 mm i.d. $\times 250 \mathrm{~mm}$, 関東化学）を用い, カラム温度 $40{ }^{\circ} \mathrm{C}$ で分析を行った。溶出溶媒に溶媒 A（10\% 酢酸-5\% アセトニトリル，v/v）と溶媒 B (10\%酢酸-50\%アセトニ トリル, $\mathrm{v} / \mathrm{v})$ を用いた。 分析は 45 分で溶媒 B の濃度が 20\%，50 分で 70\% とする直線濃度勾配で行った。流速は $1.0 \mathrm{ml} / \mathrm{min}$ とし, 成分の検出には 2 波長検出器 (SPD10 $\mathrm{AV}$, 島津製作所）を用い, 検出波長は $510,530 \mathrm{~nm}$ とした.

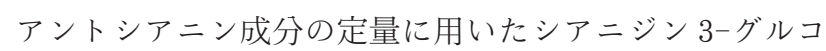

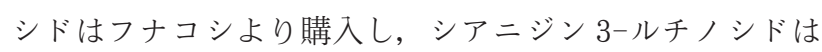
‘紅さやか’ から分離・精製したものを使用した。

\section{4. ‘紅さやか’ アントシアニンの単離・精製}

完熟果の果皮および果肉に多量の赤色素が含まれる 紅 さやか’について，主要なアントシアニンを明らかにする ため, 以下に示す方法により成分を単離・精製した。凍結 果実 $(500 \mathrm{~g})$ を $2^{\circ} \mathrm{C}$ に半解凍後, 種と軸を除去し, $5 \%$ 酢 酸 $500 \mathrm{ml}$ を添加後, 水冷しながらホモジナイザーにて処 理した（5 分間，8000 回転). $5 \%$ 酢酸 4.51 を追加し, 攪拌 後, 室温にて 24 時間静置し, アントシアニン成分の抽出を 行った.この抽出液を吸引ろ過後 (5A 版), $500 \mathrm{ml}$ のイオン 交換樹脂 DIAIONHP-20 (三菱化学製) に供し，21の蒸留 水で洗浄した。続いて 1.51 の 5\%酢酸-80\% エ夕ノール溶 液でアントシアニン成分を溶出し，これを $20 \mathrm{ml}$ に減圧濃 縮した。さらにSephadex LH-20（ファルマシア製）カラ ム $(25 \mathrm{mmi} . \mathrm{d} \times 900 \mathrm{~mm})$ を用い（エタノールにて平衡化） 分離・精製を行った。展開溶媒にはエタノールを用い，流 速は $4 \mathrm{ml} / \mathrm{min}$ とした。 各アントシアニン画分を減圧乾固 L, HPLC 溶媒 B 液 $10 \mathrm{ml}$ に溶解後, さらに分取 HPLC に て精製した。分取 HPLCには Inertsil PREP-ODS (20 mm i.d. $\times 250 \mathrm{~mm}$, GLScience) カラムを使用し, 流速 $6.0 \mathrm{ml} /$ minで溶出した。その他は分析 HPLC と同様の条件で 行った.

得られたアントシアニンは分析 HPLCにて純度の検定 を行い（検出波長 $280 \mathrm{~nm}, 360 \mathrm{~nm} 510 \mathrm{~nm}$ )，単一成分にな るまで精製を行った（ピーク面積比 $98 \%$ 以上)。溶媒除去 後, 少量の $0.05 \%$ 塩酸-メ夕ノールに溶解し, 過剰のジエ チルエーテルを加えて沈殿を生成させた。沈殿物をシリカ ゲルデシケータ中で 24 時間減圧下, 乾燥しアントシアニ ンの塩酸塩とした.

\section{HPLC によるルチンの分析・分取}

総ポリフェノール分析に使用した抽出液を，ろ紙（5A 版）およびメンブレン $(0.45 \mu \mathrm{m})$ にて順次ろ過し, HPLC 分析の試料とした. HPLC 装置およびカラムはアントシア ニンの分析あるいは分取に使用したものと同様のものを使 用した。溶出溶媒には溶媒 C（2\%酢酸-5\%アセトニトリ ル， V/v)，溶媒 D ( $2 \%$ 酢酸- $50 \%$ アセトニトリル）を用 い, 分析は, まずカラムを $10 \%$ 溶媒 D で平衡化後, D の濃 度が 25 分で $40 \%, 60$ 分で $80 \%$ となる直線濃度勾配で行っ た。流速は $1.0 \mathrm{ml} / \mathrm{min}$ とし, 検出は $280,360 \mathrm{~nm}$ で行っ た. 分取 HPLC は流速を $6.0 \mathrm{ml} / \mathrm{min}$ とし, その他は分析 HPLC と同様の条件で行った. 
表 1 オウトゥの $\mathrm{pH}$, 糖度, 総ポリフェノール ${ }^{\dagger}$

\begin{tabular}{lccc}
\hline \hline \multirow{2}{*}{ 栽培品種 } & $\mathrm{pH}$ & 糖度 & 総ポリフェノール \\
\cline { 2 - 4 } & & $($ Brix $\%)$ & $(\mathrm{mg} / 100 \mathrm{~g}$ 新鮮重 $)$ \\
\hline 佐藤錦 & $3.80 \pm 0.01$ & $22.7 \pm 2.21$ & $57.3 \pm 1.30$ \\
高 砂 & $3.81 \pm 0.02$ & $21.1 \pm 0.67$ & $66.7 \pm 2.35$ \\
紅さやか & $3.70 \pm 0.01$ & $21.8 \pm 2.92$ & $200 \pm 7.19$ \\
紅秀峰 & $3.96 \pm 0.01$ & $22.8 \pm 0.20$ & $51.8 \pm 2.23$ \\
月山錦 & $3.96 \pm 0.01$ & $17.7 \pm 0.06$ & $68.1 \pm 6.04$ \\
Napoleon & $3.54 \pm 0.01$ & $17.4 \pm 1.02$ & $117 \pm 4.92$ \\
Jabouley & $3.60 \pm 0.03$ & $13.8 \pm 0.53$ & $190 \pm 19.6$ \\
Conpactlambert & $3.72 \pm 0.01$ & $14.2 \pm 0.06$ & $71.9 \pm 3.24$ \\
Van & $3.79 \pm 0.01$ & $13.9 \pm 0.12$ & $88.1 \pm 8.82$ \\
Redglory & $3.75 \pm 0.01$ & $13.8 \pm 0.01$ & $135 \pm 19.5$ \\
Mertonfavrite & $4.08 \pm 0.01$ & $15.8 \pm 0.01$ & $145 \pm 8.21$ \\
Greatbigarreau & $4.01 \pm 0.01$ & $15.9 \pm 0.06$ & $192 \pm 6.80$ \\
Seneca & $3.65 \pm 0.01$ & $19.7 \pm 0.32$ & $367 \pm 24.0$ \\
\hline
\end{tabular}

†平均土標準偏差（1 試料につき 3 回分析）

またルチンの標準試料はフナコシより購入した.

\section{6. 機器分析による ‘紅さやか’ ポリフェノールの構造 解析}

“紅さやか’ポリフェノール各成分（アントシアニン，ル チン）を，エレクトロスプレーイオン化二重収束磁場型質 量分析計（マイクロマス社製，ZabspecQ）にて分析した。 アントシアニンの測定は, 正イオンのみを検出する陽イオ ンモードで行った (分子イオンピーク $\mathrm{m} / \mathrm{z}[\mathrm{M}]^{+}$). 配糖体 の検出はノズル電圧 $3 \mathrm{kV}$ にて分析を行い, アグリコンの 検出時には $7 \mathrm{kV}$ にて分析を行った。 また，ルチンの分析 は負イオンのみを検出する陰イオンモードで行った（分子 イオンピーク $\left.\mathrm{m} / \mathrm{z}[\mathrm{M}-\mathrm{n}]^{\mathrm{n}-}\right)$.

さらに, 単離したアントシアニンのうち, シアニジン-3ルチノシド（甘果オウトウの主要成分）に関しては ${ }^{1} \mathrm{H} 一$, ${ }^{13} \mathrm{C}-\mathrm{NMR}$ スペクトル（日本電子製，JNM-EX400FT-NMR スペクトルメーター）により構造解析を行った.

\section{実験結果および考察}

1. オウトウ果実の $\mathrm{pH}$, 糖度 (Brix), 総ポリフェノール オウトウの $\mathrm{pH}$, 糖度, 総ポリフェノールを表 1 に示す. オウトウ果実の $\mathrm{pH}$ は 3.5〜 4.1 であった. 今回分析した栽 培品種の中では, “紅秀峰” の糖度が最も高く，また，本県 で主に生食として出荷されている ‘佐藤錦”“紅さやか’ “紅秀峰”高砂”はいずれ屯，糖度が $20 \%$ を越えており， 国外の栽培品種は低い傾向を示した。

オウトウ果実の総ポリフェノール含有量はアントシアニ ン色素を多量に含み，果皮および果肉共に赤色である栽培 品種が高い值を示した。国内の主要な栽培品種の中では “紅さやか’の総ポリフェノール含有量が最も高く, ナポレ オンは果肉が赤くないにあかかわらず，他の同様な栽培品 種と比較し総ポリフェノール含有量が高い值を示した。
表 2 ‘紅さやか’ アントシアニンの主要成分

\begin{tabular}{|c|c|c|}
\hline $\begin{array}{l}\text { HPLC } \\
\text { ピーク } \\
\text { No. }{ }^{\circ}\end{array}$ & $\begin{array}{c}\text { 分子イオン } \\
\text { ピーク } \\
\mathrm{m} / \mathrm{z}[\mathrm{M}]^{+}\end{array}$ & $\begin{array}{c}\text { 同定・推定化合物 } \\
\text { (既知分子量) }\end{array}$ \\
\hline 1 & 611 & シアニジン-3-ソフォロシド $(611){ }^{* 2}$ \\
\hline 2 & 449 & シアニジン-3-グルコシド $(449) ※ 3$ \\
\hline 3 & 595 & シアニジン-3-ルチノシド $(610) * 4$ \\
\hline 4 & 633 & 未同定 \\
\hline 5 & 579 & ペラルゴニジン-3-ルチノシド $(579) \% 2$ \\
\hline 6 & 609 & ペオニジン-3-ルチノシド $(609) \% 2$ \\
\hline
\end{tabular}

※1困 1 を参照

※2分子質量（配糖体, アグリコン）より推定

${ }^{* 3}$ HPLC 分析により既知化合物と同じ保持時間を示した化合物

※4 分子質量（配糖体，アグリコン）及び 13 CNMR スペクトル より同定

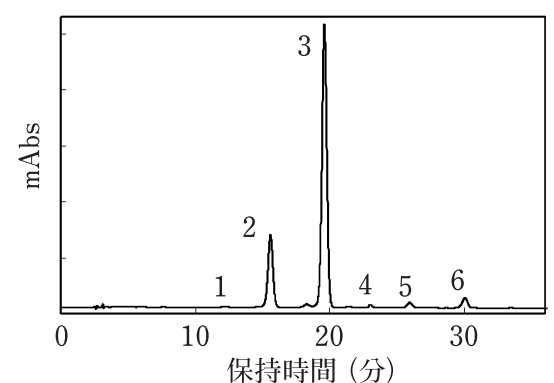

図 1 ‘紅さやか’ アントシアニンの HPLC クロマトグラム (510 $\mathrm{nm}$ 検出)

\section{2. ‘紅さやか’ のアントシアニン成分}

“紅さやか’ アントシアニン成分の HPLC クロマトグラ ムを図 1 に示す。“紅さやか’に扮いて 6 つの主要なアント シアニンのピークが検出された（ピーク No 1〜6).これら ピークの成分を単離・精製処理後, エレクトロスプレーイ オン化質量分析計 (以下 ESI-MS) にて分子量測定し, 各ア ントシアニンに対する解析を行った。 ESI-MS 分析によっ て検出された，各成分の分子イオンピーク $(\mathrm{m} / \mathrm{z})$ を表 2 に示す。 ESI-MS 分析では配糖体由来の分子イオンピーク $\left([\mathrm{M}]^{+}\right)$とアグリコン由来のフラグメントイオンを検出す ることが可能であった。 ピーク No. 2 は, ESI-MS にて m/ z449 $\left([\mathrm{M}]^{+}\right)$に分子イオンピークを, $\mathrm{m} / \mathrm{z} 287$ にシアニジ ンによるフラグメントイオンが検出され，さらに， HPLC 分析による保持時間が標準試薬と一致したことから，シア ニジン-3-グルコシドと同定された.

ピーク No. 3 は ESI-MS で m/z595 $\left([\mathrm{M}]^{+}\right)$に分子イオ ンピークを, $\mathrm{m} / \mathrm{z} 287$ にシアニジンによるフラグメントイ オンを示した。 また， ${ }^{13} \mathrm{CNMR}(100 \mathrm{MHz}, \mathrm{CF} 3 \mathrm{COOD}-\mathrm{CD}$ $3 \mathrm{OD}=1-9, \mathrm{TMS}, \delta \mathrm{ppm})$ スペクトルでは $164.47(\mathrm{C}-2)$, 145.68 (C-3), 136.51 (C-4), 159.37 (C-5), 103.77 (C-6), 170.79 (C-7), 95.47 (C-8), 157.96 (C-9), 113.52 (C-10), $121.47\left(\mathrm{C}-1^{\prime}\right), 118.71\left(\mathrm{C}-2^{\prime}\right), 147.68\left(\mathrm{C}-3^{\prime}\right), 156.13\left(\mathrm{C}-4^{\prime}\right)$, 
$117.69\left(\mathrm{C}-5^{\prime}\right), 128.62\left(\mathrm{C}-6^{\prime}\right), 112.77\left(\mathrm{C}-1^{\prime \prime}\right), 74.91\left(\mathrm{C}-2^{\prime \prime}\right)$, 77.69 (C-3"), 71.47 (C-4"), $78.26\left(\mathrm{C}-5^{\prime \prime}\right), 68.07\left(\mathrm{C}-6^{\prime \prime}\right)$,

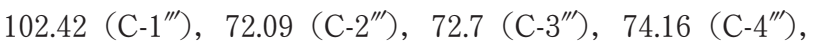
70.09 (C-5"'), 18.11 (C-6"') に各シグナルを示した.これは 既報7)におけるシアニジン-3-O-ルチノシド (図 2) のカー ボンのケミカルシフト值と一致したことから，ピーク No. 3 はシアニジン-3-ルチノシドと同定された.

また, ESI-MS 分析の結果, ピーク No. 1 （分子イオン ピーク $\mathrm{m} / \mathrm{z} 611$ ， アグリコン由来フラグメントイオン $\mathrm{m} / \mathrm{z}$ 287）および，ピーク No. 5 （分子イオンピーク $\mathrm{m} / \mathrm{z} 579$ ，ア グリコン由来フラグメント $\mathrm{m} / \mathrm{z} 271$ ), ピーク No. 6 (分子 イオンピーク $\mathrm{m} / \mathrm{z} 609$ ， アグリコン由来フラグメント $\mathrm{m} / \mathrm{z}$ 301）のそれぞれは, 甘果オウトウにおいてその存在が既に 報告8) されている，シアニジン-3-ソフォロシド（分子量 611), ペラルゴニジン-3-ルチノシド (分子量 579), ペオニ ジン-3-ルチノシド（分子量 609）と推定された。

3. オウトゥ各栽培品種のシアニジン-3-ルチノシドお よびシアニジン-3-グルコシド含有量

甘果オウトウではシアニジン-3-ルチノシドとシアニジ ン-3-グルコシドが主要なアントシアニンであることが報 告されている ${ }^{8) 9}$. また, HPLC 分析の結果, この 2 成分の ピーク面積の合計は，今回分析したすべての栽培品種にお いて，アントシアニン総ピーク面積の $90 \%$ 以上を占めて



図 2 シアニジン-3-0-ルチノシドの化学構造
おり，本報告でも同様の傾向が認められた。

オウトウ各栽培品種のシアニジン-3-ルチノシドおよび シアニジン-3-グルコシド含有量を表 3 に示す。また，こ れらアントシアニン含有量が高い值を示した 'Seneca’ 'Greatbigarreau’ 'Jabouley' の HPLCクロマトグラムを 図 3 に示す。今回分析に用いたオウトウのなかで，アント シアニン含有量が, 新鮮重あたり最む高い品種は, 'Seneca' （シアニジン-3-ルチノシド $162 \mathrm{mg} / 100 \mathrm{~g}$, シアニジン-3グルコシド $69 \mathrm{mg} / 100 \mathrm{~g}$ ）であり，国内で栽培される品種 では ‘紅さやか’（シアニジン-3-ルチノシド $73.8 \mathrm{mg} / 100$ $\mathrm{g}$, シアニジン-3-グルコシド $14.3 \mathrm{mg} / 100 \mathrm{~g}$ ) であった.

“紅さやか’は‘佐藤錦”と ‘Seneca' を交配して選抜・ 育種された品種であり, 系統的に食味が良く（糖度が高 く)，アントシアニン含有量が高いことが推察されてい た ${ }^{10)}$ が，本研究ではそれを支持する結果が得られた。

また，果皮が黄色であり，果肉が白い'月山錦”からはい ずれのアントシアニン成分む検出することができなかった。

\section{4. オウトウ各品種のルチン含有量}

Goncalves ら ${ }^{8)}$ は，完熟したオウトウにルチンが含まれ

表 3 オウトウの主要アントシアニン含有量 ${ }^{\dagger}$

$(\mathrm{mg} / 100 \mathrm{~g}$ 新鮮重)

\begin{tabular}{lcc}
\hline \hline \multicolumn{1}{c}{ 栽培品種 } & シアニジン-3-ルチノシド シアニジン-3-グルコシド \\
\hline 佐藤錦 & $0.569 \pm 0.170$ & $0.023 \pm 0.004$ \\
高 砂 & $0.228 \pm 0.050$ & $\mathrm{n} . \mathrm{d}$ \\
紅さやか & $73.8 \pm 0.47$ & $14.3 \pm 0.140$ \\
紅秀峰 & $0.340 \pm 0.063$ & $\mathrm{n} . \mathrm{d}$ \\
月山錦 & $\mathrm{n} . \mathrm{d}$ & $\mathrm{n} . \mathrm{d}$ \\
Napoleon & $0.599 \pm 0.047$ & $0.027 \pm 0.003$ \\
Jabouley & $67.2 \pm 6.41$ & $7.18 \pm 0.673$ \\
Conpactlambert & $6.10 \pm 1.48$ & $0.130 \pm 0.030$ \\
Van & $9.60 \pm 0.84$ & $0.192 \pm 0.022$ \\
Redglory & $14.6 \pm 0.01$ & $1.19 \pm 0.025$ \\
Mertonfavrite & $41.0 \pm 4.78$ & $2.28 \pm 0.314$ \\
Greatbigarreau & $80.5 \pm 2.53$ & $2.84 \pm 0.090$ \\
Seneca & $162 \pm 6.24$ & $69.0 \pm 2.49$ \\
\hline
\end{tabular}

†平均土標準偏差（1 試料につき 3 回分析）
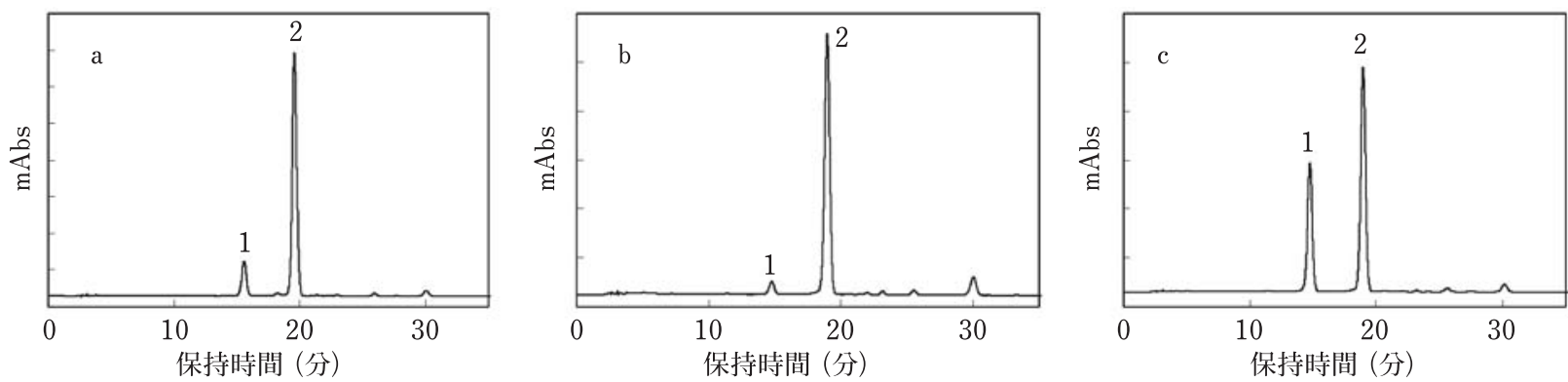

図 3 オウトゥアントシアニンの HPLC クロマトグラム（510 nm 検出）

ピーク No. 1 : シアニジン 3-グルコシド，ピーク No. 2 : シアニジン $3-$ ルチノシド a : Jabouley, b : Greatbigarreau, c : Seneca 

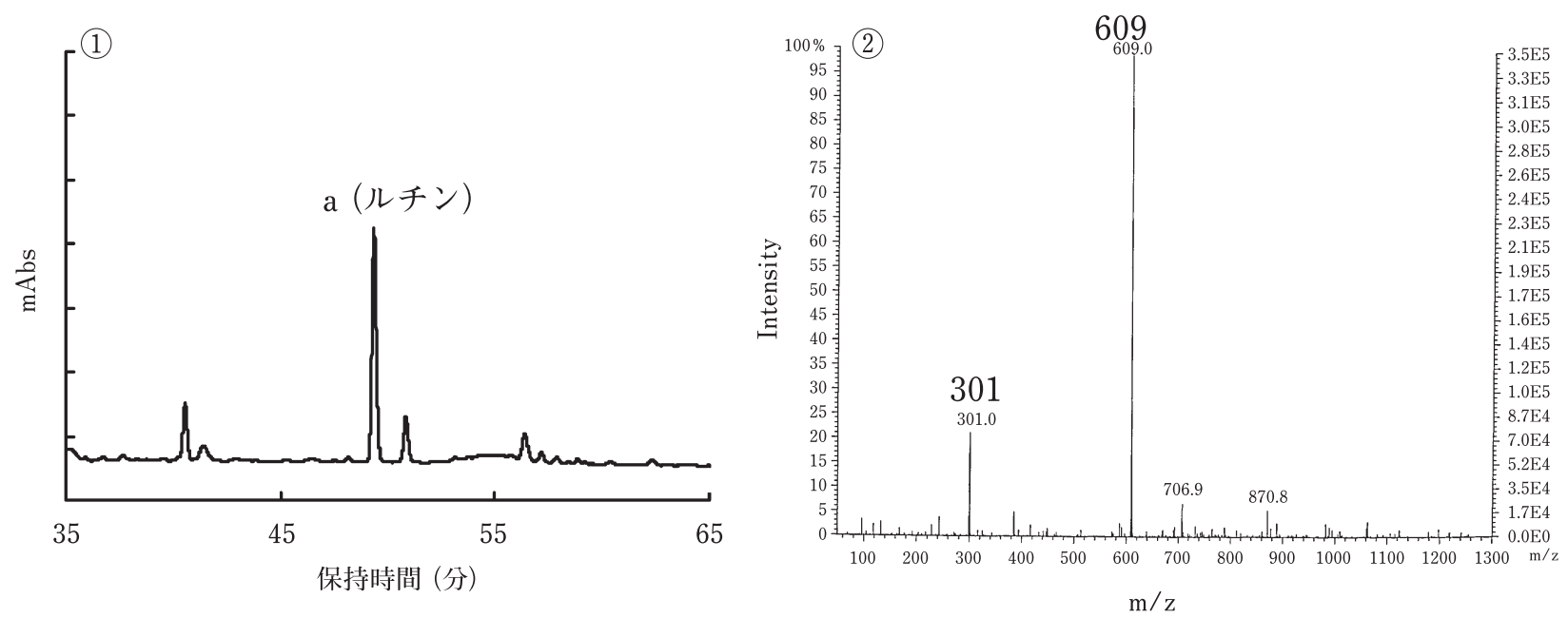

図 4 “紅さやか’ フラボノイドの HPLC クロマトグラムと ESI-MS スペクトル

(1) : HPLC クロマトグラム $(360 \mathrm{~nm})$, 成分 a はルチン（標準試薬）と保持時間が一致

(2) : HPLC クロマトグラム成分 a の ESI-MS スペクトル, 分子イオンピーク $(\mathrm{m} / \mathrm{z} 609)$ :

$[\mathrm{M}-\mathrm{H}]-(\mathrm{M}:$ 化合物の分子量 $)$, フラグメントイオン $(\mathrm{m} / \mathrm{z} 301)$

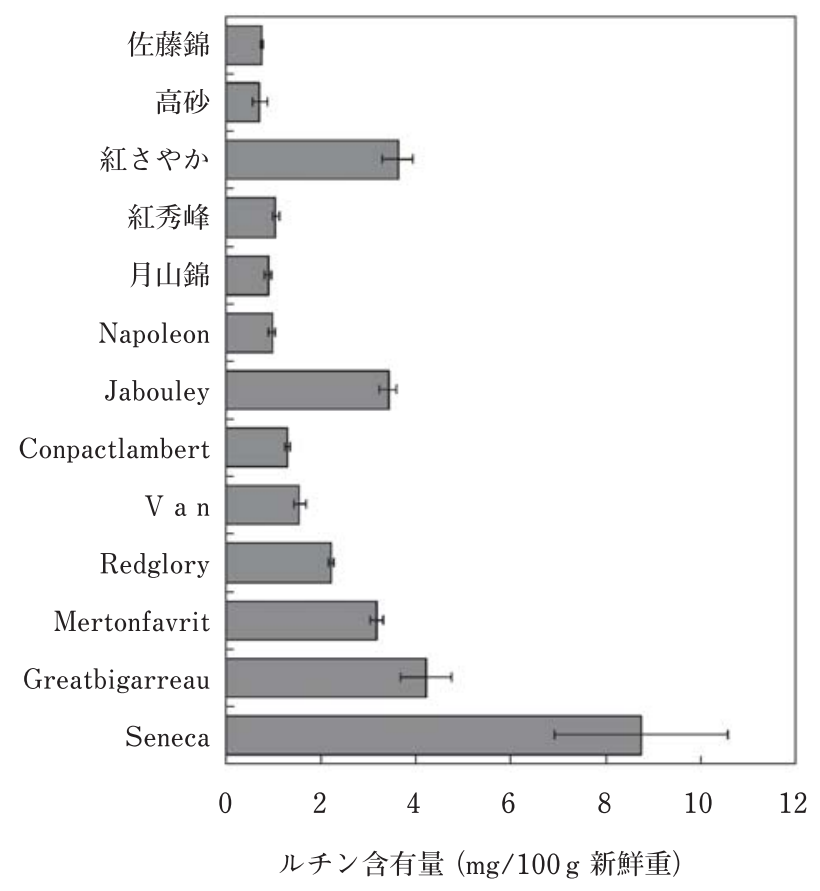

図 5 オウトゥ（甘果 13 栽培品種）のルチン（ケルセチン3-ルチノシド) 含有量

各果実について 3 回分析, 分析值は平均土標準偏差

ていることを報告している。 ‘紅さやか’に含まれるフラボ ノイド成分を HPLC，および ESI-MS により分析したとこ ろ, HPLC 分析にてルチンを検出する（標準試料と保持時 間が一致）とと屯に, ESI-MS にてルチン（分子イオンピー ク $\mathrm{m} / \mathrm{z} 609$ : [M-1] $\left.{ }^{-}\right)$およびアグリコンであるケルセチ ン（フラグメントイオン $\mathrm{m} / \mathrm{z} 301:[\mathrm{M}-1]^{-}$) を確認するこ とができた（図 3).さらに，今回分析に用いたすべてのオ ウトウについて，ルチンを検出することが可能であった.



図 6 オウトゥ（甘果 13 栽培品種）のシアニジン-3-ルチノ シド含有量とルチン含有量との相関

オウトウのルチン定量分析結果を図 4 に示す.オウトウの ルチン含有量は $0.8 \sim 8.7 \mathrm{mg} / 100 \mathrm{~g}$ 程度であり, 甘果オウ トウの場合, ‘Seneca’ ‘Greatbigarreau’ 'Jabouley’ ‘紅 さやか’など果皮・果肉が赤色のオウトウほどルチン含有 量が高い傾向にあり，甘果オウトウにおいて，アントシア ニンの主要成分であるシアニジン-3-ルチノシドは，ルチ ン含有量との間に高い正の相関を示した $\left(\mathrm{R}^{2}=0.97\right)$ (図 5).さらに，ルチン含有量は総ポリフェノール含有量との 間においても高い相関を示した $\left(\mathrm{R}^{2}=0.95\right.$ ) (図 6). 一般的 に, 果実や野菜のアントシアニンの生合成経路としては, マロニル-CoA（3 分子） および p-クマロイル-CoA から カルコンシンターゼの働きにより, $2^{\prime}, 4^{\prime}, 6^{\prime}, 4-\mathrm{t}-$ ヒドロキ シカルコンが合成され，フラバノン，ジヒドロフラボノー ル，ロイコシアニジンを経てアントシアニジンが生成す 


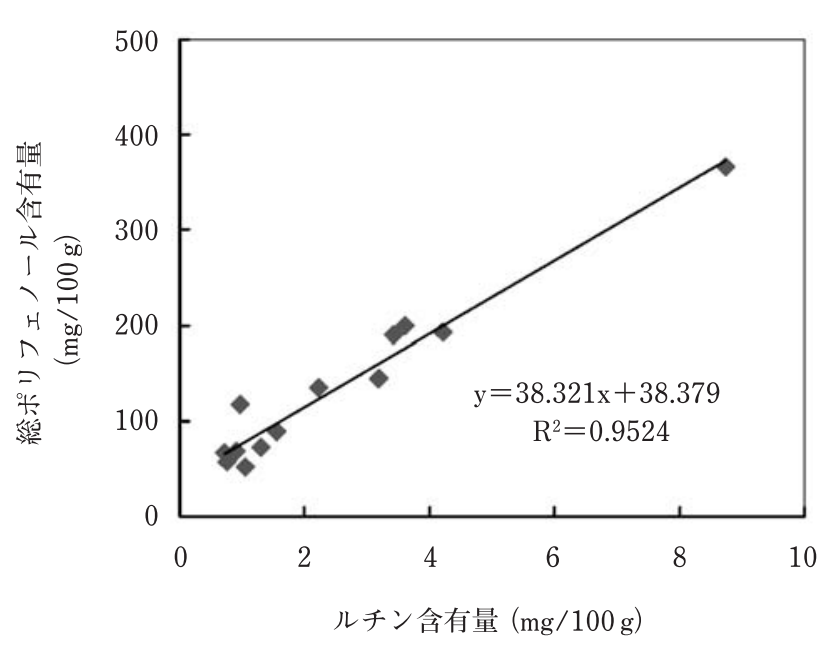

図 7 オウトゥ（甘果 13 栽培品種）の総ポリフェノール含 有量とルチン含有量との相関

る ${ }^{11)}$. アントシアニジン $\mathrm{B}$ 環の水酸化は 2 つの過程が報告 されているが12), いずれの場合においても, オウトウでは 主要なアントシアニジンであるシアニジンが合成される過 程で, ジヒドロケルセチン（ジヒドロフラボノール）が合 成されると推察される。 また，ジヒドロケルセチンの代謝 経路としては, ジヒドロフラボノール-4-レダクターゼの 作用によりロイコシアニジンが合成される一方で, ケルセ チン（フラボノール）が合成されると考えられる. シアニ ジンおびケルセチンの 3 位水酸基の配糖体化には共にフ ラボノイド-3-グリコシルトランスフェラーゼが関与す る ${ }^{13)}$. ケルセチンの場合ケルセチン-3-グルコシドが生産 され, さらにフラボノイド-3-グルコシドラムノシルトラ ンスフェラーゼ13) が作用し， 3 位に結合したグルコースに ラムノースが順次結合し，ルチノース配糖体であるルチン が生成すると考えられる。 ‘月山錦”のような果皮・果肉に 全くアントシアニンを含まない栽培品種にもルチンが検出 されたことから，アントシアニン色素を含まないオウトウ であっても, ジヒドロケルセチンまでの生合成経路が存在 することが示唆された。

\section{要 約}

山形県農業生産技術試験場の固場にて栽培されている甘 果オウトウ 13 栽培品種について, 主要なアントシアニン を同定・定量するとともに，アントシアニン含有量とアン トシアニンと同じ糖構造を有するフラボノイド（ルチン） 含有量との関係を明らかにした。

果皮・果肉が赤い甘果オウトウである ‘紅さやか’のア ントシアニンを同定した。果実から $5 \%$ 酢酸にてアントシ アニンを抽出し, ダイヤイオン HP20, セファデックス LH 20 カラムクロマトグラフィー, HPLCにてアントシアニ ンを精製した後, アントシアニンの化学構造を HPLC,
ESI-MS, ${ }^{1} \mathrm{H},{ }^{13} \mathrm{CNMR}$ にて同定した。“紅さやか’ には，5 種の主要なアントシアニンが含まれ, 主要成分としてシア ニジン-3-ルチノシド及びシアニジン-3-グルコシドが同定 され, ペオニジン-3-ルチノシド, ペラルゴニジン-3-ルチ ノシド, シアニジン-3-ソフォロシドが微量成分として同 定された。 日本で栽培される主要な甘果オウトウ果実（7 栽培品種）のシアニジン-3-ルチノシド濃度は検出限界以 下から $73.8 \mathrm{mg} / 100 \mathrm{~g}$ (新鮮重) であり, “紅さやか’の含有 量が最む高い值を示した。 オウトウ果実のフラボノイドと して, ルチンが検出され，その含有量は 0.7-8.7 mg/100 g (新鮮重) であった。 甘果オウトウ（13 栽培品種）におい て, アントシアニンの主要成分であるシアニジン-3-ルチ ノシド含有量とルチン含有量との間には高い相関 $\left(\mathrm{R}^{2}=\right.$ 0.97）が見られた.

\section{文献}

1）農林水産省統計部生産流通統計課, 平成 18 年産果樹生産出 荷統計，（2007）.

2）白井勝也, 園芸植物大辞典, 小学館, 380-385（1994）.

3) Wanng, H., Nair, M.G., Stransburg, G.M., Booren, AM. and Gray, J.I., Antioxidant polyphenols from tart cherries (Prunus cerasus), J. Agric Food Chem., 47, 840-844 (1999).

4) Seeram, N.P., Momin, R.A., Nair, M.G. and Bourquin, L. D., Cycloxygenase inhibitory and antioxidant cyanidin glycoside in cherries and berries, Phyto-medicine., 8, 362369 (2001).

5) Blando, F., Gerardi, C. and Nicoletti, I., Sour Cherry (Prunus cerasus L) Anthocyanins as Ingredients for Functional Foods, J. Biomed Biotecnol., 5, 253-258 (2004).

6）（財）日本食品分析センター，5訂日本食品標準成分表分析 マニュアルの解説，254-256 (2001).

7) Wang., H., Nair, M.G., Iezzoni, A.F., Strasburg, G.M., Booren, A.M. and Gray, J.I., Quantification and characterization of anthocyanins in Balaton Tart cherries, J. Agric Food Chem., 45, 2556-2560 (1997).

8) Goncalves, B., Landbo, A.K., Knudsen, D., Silva, A.P., Moutin-ho-Pereira, J., Rosa, E. and Meyer, A.S., Effect of ripeness and postharvest storage on the phenolic profiles of Cherries (Prunus avium L), J. Agric Food Chem., 11, 523-530 (2004).

9) Branka, Mozetic., Polonca, Trebse.,Janez Hribar., Determination and quantitation of anthocyanins and hydroxycunamic acids in different cultivars of sweet cherries (Prunus avium L.) from Nova Gorica Region (Slovenia), Food Teachnol. Biotecnol., 40, 207-212 (2002).

10）佐藤 巧, 石黒 亮, 新野 清, 野口協一, オウトウ新品種 “紅さやか’ ‘紅秀峰’ について, 山形県立園芸試験場研究報 告, 10, 1-21 (1993).

11）大庭理一郎, 五十嵐喜治, 津久井亜紀夫, アントシアニン・ 食品の色之健康 (建帛社), p. 29 (2000).

12）大庭理一郎, 五十嵐喜治, 津久井亜紀夫, アントシアニン・ 食品の色之健康（建帛社）, p. 30（2000）.

13）大庭理一郎, 五十嵐喜治, 津久井亜紀夫, アントシアニン・ 食品の色之健康 (建帛社), p. 30-31（2000）。

(平成 19 年 11 月 9 日受付, 平成 20 年 2 月 1 日受理) 